This version of this paper is non-peer-reviewed and under review in Nature Geoscience

This paper has been submitted for publication to Nature Geoscience on June 82020 A revised version of this paper has been submitted on December 152020 and is under review.

Any comment can be sent to the corresponding author: feuillet@ipgp.fr 


\section{Birth of a large volcanic edifice through lithosphere-scale dyking offshore Mayotte (Indian Ocean)}

N. Feuillet ${ }^{1}{ }^{*}$, S.J. Jorry ${ }^{2}$, W. Crawford ${ }^{1}$, C. Deplus ${ }^{1}$, I. Thinon ${ }^{3}$, E. Jacques ${ }^{1}$, J.M. Saurel ${ }^{1}$, A. Lemoine $^{3}$, F. Paquet ${ }^{3}$, C. Satriano ${ }^{1}$, C. Aiken ${ }^{2}$, O. Foix ${ }^{1}$, P. Kowalski ${ }^{1}$, A. Laurent ${ }^{1}$, E. Rinnert $^{2}$, C. Cathalot ${ }^{2}$. J.P. Donval ${ }^{2}$, V. Guyader ${ }^{2}$, A. Gaillot ${ }^{2}$, C. Scalabrin ${ }^{2}$, M. Moreira ${ }^{1}$, A. Peltier $^{1}$, F. Beauducel ${ }^{1,4}$, R. Grandin ${ }^{1}$, V. Ballu ${ }^{5}$, R. Daniel ${ }^{1}$, P. Pelleau ${ }^{2}$, J. Gomez ${ }^{1}$, S. Besançon $^{1}$, L. Geli ${ }^{2}$, P. Bernard ${ }^{1}$, P. Bachelery ${ }^{6}$, Y. Fouquet ${ }^{2}$, D. Bertil ${ }^{3}$, A. Lemarchand ${ }^{1}$, J. Van der Woerd ${ }^{7}$.

1- Université de Paris, Institut de physique du globe de Paris, CNRS, F-75005 Paris, France

2- IFREMER, Unité Géosciences Marines, Technopole La Pointe du Diable, 29280 Plouzané, France

3- Bureau de Recherches Géologiques et Minières - BRGM, DGR/GBS, F-45060 Orléans, France

4- Université Grenoble Alpes, IRD, ISterre

5- LIttoral ENvironnement et Sociétés (LIENSs) UMR7266, Université de La Rochelle CNRS, 2 rue Olympe de Gouges, 17000 La Rochelle

6- Université Clermont Auvergne, CNRS, IRD, OPGC, Laboratoire Magmas et Volcans, F-63000 Clermont-Ferrand, France,

7- Institut de Physique du Globe de Strasbourg UMR7516 CNRS Université de Strasbourg, 5 rue René Descartes 67000 Strasbourg, France

Volcanic eruptions are foundational events that shape the Earth's surface and provide a window into deep Earth processes. How the primary asthenospheric melts form, pond and ascend through the lithosphere is, however, still poorly understood. We document an on-going magmatic event offshore Mayotte Island (North Mozambique channel), associated with large surface displacements, very low frequency earthquakes and

exceptionally deep $(25-50 \mathrm{~km})$ seismicity swarms. We present data from the May 2019

MAYOBS1 cruise, which reveal that this event gave birth to a $820 \mathrm{~m}$ tall, $\sim 5 \mathrm{~km}^{3}$ deepsea volcanic edifice. This is the largest active submarine eruption ever documented. The data indicate that deep magma reservoirs were rapidly drained through dykes that intruded the entire lithosphere and that pre-existing subvertical faults in the mantle 
The new volcanic edifice is located at the tip of a $50 \mathrm{~km}$-long volcanic ridge on the

eastern insular slopes of Mayotte. The ridge is composed of many other recent edifices and lava flows and is an extensional feature that opens inside a wide transtensional boundary to transfer the strain between the East-African and Madagascar rifts. A hot asthenosphere at the base of a thick damaged lithosphere could be at the origin of this massive eruption.

Since May 10 2018, Mayotte Island (Comoros archipelago, north Mozambique Channel between Africa and Madagascar, Figure 1a) has experienced a major magmatic event off its eastern coast. This event generated more than 11000 detectable earthquakes (up to Mw 5.9), surface deformation rates of up to $200 \mathrm{~mm} /$ year and unusual very low frequency (VLF) earthquakes ${ }^{1,2,3}$. As of December 2020 (the time of writing), Mayotte is still deforming and both VLF events and earthquakes with Mw up to 5 are still being recorded.

Prior to this event, no recent eruption or significant seismic activity was reported around Mayotte. Only two earthquakes were detected within $100 \mathrm{~km}$ of the island by the global network since $1972^{4}$ and the most recent volcanic exposure is a 4-6 kyr-old pumice layer sampled in the lagoon surrounding the island ${ }^{5}$.

Recent geodynamic reconstructions suggest that the archipelago was built on $\sim 150$ Ma old oceanic lithosphere accreted to accommodate the opening of the Western Somali Basin ${ }^{6}$. This Comorian volcanism may result from partial melting of the base of this old oceanic lithosphere in interaction with plume material ${ }^{7,89}$ possibly super plumes originating from Africa $^{10,11,12}$. This volcanism may have been controlled by reactivation of the fractures zones ${ }^{13}$ or by diffuse zones of right-lateral shear deformation ${ }^{14}$. Subaerial volcanic activity on Mayotte 
island began $11 \mathrm{My}$ ago ${ }^{13}$. Well-preserved cones, tuff rings and maar craters in the Northeastern part of the island (on Petite Terre and in and around Mamoudzou ${ }^{15,7}$ and further offshore $^{16}$ (Figure 1b) testify to relatively recent (probably Holocene ${ }^{7}$ ) subaerial explosive volcanic activity. Gas emissions on Petite-Terre with a high percentage of carbon dioxide and helium indicate magma degassing ${ }^{17}$.

\section{The discovery of the new volcanic edifice}

The French national research program "SISMAYOTTE" was launched in February 2019 to determine the origin of the seismicity and deformation, to search for any seafloor volcanic activity and to understand the scale, chronology and implications of the crisis. As part of this program, we 1) set up seismic and Global Navigation Satellite System (GNSS) stations on Mayotte and Grande Glorieuses Islands, 2) deployed Ocean Bottom Seismometers (OBS) with attached Absolute Pressure Gauges (APG) around the seismic swarm area, and 3) acquired high-resolution marine data (bathymetry, seafloor and water column backscatter, sub-bottom, magnetic and gravity profiles), rock dredges and CTD (ConductivityTemperature-Depth)- Rosette during the MAYOBS1 cruise aboard the R/V Marion Dufresne ${ }^{18}$.

A systematic $12 \mathrm{kHz}$ multibeam echosounder survey east of Mayotte revealed a $820 \mathrm{~m}$ tall new volcanic edifice (NVE) $50 \mathrm{~km}$ east of Mayotte (Figure 1). The NVE was detected by comparing our data to those acquired during a 2014 survey by the French Naval Hydrographic and Oceanographic Service $(\mathrm{SHOM})^{19}$ (Figure $\left.2 a\right)$. The edifice sits on an area that, in the 2014 seafloor topography, was locally almost flat at around $3300 \mathrm{~m}$ below sea level (bsl).

\section{The Mayotte volcanic ridge}

The NVE has grown on the lower insular slope of Mayotte, near the end of a WNW-ESE trending volcanic ridge (Mayotte ridge) emplaced on the submarine flank of Mayotte (Figure 
1). The NVE and many other volcanic features along the ridge are highly reflective in seafloor imagery (Figure 1c and extended data Figures 1,3) indicating recent volcanic activity all along the ridge. The ridge is $50 \mathrm{~km}$ long, extending from the most recent subaerial cones and maar craters on Grande-Terre and Petite-Terre islands (MPT Volcanic zone) to the NVE (Figure 1b). It is segmented into two main parts: an upper slope volcanic zone (western segment) and a mid- to lower-slope zone (eastern segment). The eastern segment trends $\mathrm{N} 130^{\circ} \mathrm{E}$ and is made of many constructional features similar to mafic submarine eruption features observed elsewhere ${ }^{20,21,22}$ : cones up to $2 \mathrm{~km}$-wide and $500 \mathrm{~m}$-high, probably monogenetic; high backscatter zones with smooth bathymetry, which could correspond to recent lava flows; elongated ridges with steep slopes and varying orientations, which could result from dykes in more sedimented areas (Figure 1 and extended data Figure 2d,e).

The western segment is made of volcanic features having more complex morphologies and emplaced along different directions (Figure $1 b$ and extended data Figure 2b,c). The main features are: i) Two $\mathrm{N} 40^{\circ} \mathrm{E}$ and $\mathrm{N} 120^{\circ} \mathrm{E}$ trending sets of cones and lava flows, with high backscatter, northeast and southeast of Petite-Terre, respectively. These sets converge to prolong the onshore maar craters of Petite-Terre and may have emplaced along pre-existing fractures or faults; ii) a horse-shoe shaped edifice (the Horseshoe) with a $3.5 \mathrm{~km}$ wide cone, steep slopes and a large collapse-induced scar. East of the Horseshoe, several smaller cones and volcanic features are aligned E-W, suggesting eruptive fissures. Large lava flows characterized by high backscatter and rough bathymetry likely originate from this fissure system. iii) a $4 \mathrm{~km}$-wide circular structure (the Crown), whose rim is crowned by seven $1 \mathrm{~km}-$ wide, 100-150m high volcanic cones. Their arrangement suggests typical post-caldera domes ${ }^{23,24}$. West of the Crown, submarine canyons and slope failure scars all terminate at a N-S trending slope break that may be controlled by faulting. The Crown appears to be located in a 
larger $10 \mathrm{~km}$ wide flat depression, which is bounded by faults and fissures and could be the remnant of an ancient caldera collapse.

\section{The new volcanic edifice and the eruptive plume}

The NVE is located at the eastern tip of the eastern segment of the Mayotte ridge (Figures 1b). In May 2019, its summit rose to $2580 \mathrm{~m}$ bsl. The highest and central part of the NVE resembles a pyramid with steep and smooth slopes (Figure $2 a$ and extended data Figure 3). Radial ridges, up to $5 \mathrm{~km}$ long and $300 \mathrm{~m}$ thick, develop from the central part. The ridges display hummocky morphology similar to that observed along mid-ocean volcanic ridges ${ }^{25}$ and active seamounts ${ }^{22}$ and probably correspond to coalesced pillow lava mounds ${ }^{21}$. Beyond and in-between the hummocky ridges, flat areas up to $100 \mathrm{~m}$ thick, with high backscatter, could indicate channelized lava flows or sheet flows emplaced at high effusion rates ${ }^{26,27}$. We calculate the volume of material corresponding to the 2014- 2019 seafloor depth difference to be at least $5.0 \pm 0.3 \mathrm{~km}^{3}$. Popping fragments of very fresh basanitic pillow lavas $(\mathrm{SiO} 247$ $\mathrm{wt} \%, \mathrm{Na}_{2} \mathrm{O}+\mathrm{K}_{2} \mathrm{O} 7.1 \mathrm{wt} \%, \mathrm{MgO} 5.7 \mathrm{wt} \%{ }^{28}$ ) were dredged on the northeastern flank of the NVE, near its summit (see Figure $2 a$ for sample location and supplementary material S1). The lavas, similar to other basanites sampled in northern Mayotte ${ }^{7}$ are aphyric with rare microphenocrysts of olivine (Fo70) and Ti-magnetite.

A 1900-m high, vertical acoustic plume, rising through the water column from the summit of the NVE to $\sim 800 \mathrm{~m}$ below the sea surface, was imaged several times during the cruise using the ship-borne multibeam echosounder (Figure 3, supplementary movie 1). A vertical CTD/rosette cast to $3137 \mathrm{~m}$ depth above the northern flank of the NVE, 1000m away from the acoustic plume, showed strong geochemical signatures. High volatile concentrations $\left(\mathrm{H}_{2}=\right.$ 550nM, $\left.\mathrm{CH}_{4}=831 \mathrm{nM}, \mathrm{CO}_{2}=34 \mu \mathrm{M}\right)$, high turbidity and high total alkalinity values were associated with temperature and $\mathrm{pH}$ anomalies (respectively $0.2^{\circ} \mathrm{C}$ and $1 \mathrm{pH}$ unit) ${ }^{29}$ and supplementary material). Such chemical anomalies are characteristic of submarine eruptions 
and may reflect magma degassing ${ }^{30}$, molten lava interaction with seawater ${ }^{31}$ or fluid/water discharge from subsurface storage zones in the crust or sedimentary cover ${ }^{32}$. The height and the strong backscatter signature of the acoustic plume suggest that a mixture of solid particles (pyroclastic/hyaloclastic jet ${ }^{30}$ ) and/or differentiated fluid phases (droplets, hydrate-coated bubbles or free gas ${ }^{33}$ ) are driven upward through the water column from the summit of the $\mathrm{NVE}^{34}$. High turbidity measured, below $2500 \mathrm{~m}$, on the northern flank of the NVE, likely indicates the presence of these particles ${ }^{35,36}$. Both the multiple observations of this vertical acoustic plume at the summit of the NVE and the high $\mathrm{H}_{2}$ concentration $1 \mathrm{~km}$ away indicate that the eruption was likely on-going in May $2019^{31}$.

In the upper slope zone, $30 \mathrm{~km}$ far from the volcano, two, $1000-\mathrm{m}$ high acoustic plumes were detected in the water column, above the Horseshoe edifice (Figure 1 and extended data Figure 5, movie 2) but no significant change in the seafloor morphology and reflectivity was detected there.

\section{The seismicity and VLF events relocated by OBS data}

The combined land-OBS network of seismic stations (supplement Figure S2.1) detected 17000 events between February 25 and May 6, 2019. We manually relocated about 800 of the largest earthquakes onboard (see method and supplementary S2). Ninety-four percent of the earthquakes cluster in the upper slope volcanic zone (western segment of the Mayotte ridge), $40 \mathrm{~km}$ west of the NVE and 5 to $15 \mathrm{~km}$ east of Petite-Terre (swarm 1, Figure 1). Almost all of the remaining events lie in a secondary swarm beneath the northwestern tip of the eastern segment, $30 \mathrm{~km}$ from Petite-Terre and $20 \mathrm{~km}$ from the NVE (swarm 2, Figure 1). A few events are also scattered along this segment. Despite a full search of the OBS-land catalog for events beneath the NVE, we found none. The earthquakes are very deep, ranging from $25 \pm 5$ to $50 \pm 5 \mathrm{~km}$. All P-S arrival delays recorded by an OBS deployed for $48 \mathrm{~h}$ above the main 
swarm were greater than 3 seconds, indicating no events less than $20 \mathrm{~km}$ depth (Figure 4, extended data Figure 6b, method and supplementary material S2). The combined land-OBS network dataset do not show any evidence for seismicity migration, but it only represents a two-month "snapshot" of the activity. To extend the observation time window, we carefully relocated 139 earthquakes recorded by the land stations between the beginning of the crisis (May 2018) and the first OBS deployment (February 2019). All the events were beneath the volcanic ridge (extended data figure 6a). During the first weeks of the crisis, these events were mainly located beneath the northwestern tip of eastern ridge segment between 30 and 50 $\mathrm{km}$ depth. In the last two weeks of June, a few events occurred between $30 \mathrm{~km}$-depth and the surface, and closer to the NVE.

In addition to the high frequency seismicity, VLF events were recorded by the OBSs wideband hydrophones. Their waveforms are similar to those of the globally detected November 112018 event (exponentially decaying monochromatic signals of approximately 2000s duration, with dominant period of $\sim 15$ s and polarized Rayleigh waves), suggesting repeated excitation of the same radiating source. We located 84 VLF events using waveform cross-correlation (see method and supplementary material S2), all of them are most probably above seismic swarm 1 (Figures 4 and extended data Figure 6b), at a mean depth of $22 \pm 15$ $\mathrm{km}$.

\section{GNSS data and APG modeling}

The GNSS network includes nine stations on Mayotte Island and two far field stations at Diego Suarez and Grande Glorieuse islands. The geometry is not optimal, preventing geodetic inversions for complicated structures or media. We performed Bayesian inversions ${ }^{37}$ of the data using a point source in an elastic half-space with two distinct analytical formalisms: an isotropic point source ${ }^{38}$ and a point compound dislocation model (pCDM ${ }^{39}$ see method, 
supplementary material S3, extended data Figure 7). In both cases, the results indicate $\sim 5 \mathrm{~km}^{3}$ deflation of a deep reservoir $(>30 \mathrm{~km})$. The simplest and most robust model indicates the deflation of $\sim 40 \mathrm{~km}$ deep isotropic source below the eastern segment of the Mayotte ridge. An increase in absolute seafloor pressure measured by all APGs on the OBS frames, interpreted as seafloor subsidence, is compatible with these models (see method, supplementary S3, extended data Figure 7d).

\section{Magma reservoirs and chronology of the eruption}

Most of the seismicity and the GNSS sources models are deep and lie in the lithospheric mantle beneath the Moho, which is estimated to be $\sim 17 \mathrm{~km}$ deep beneath Mayotte ${ }^{40}$. Seismicity this deep is rarely documented in a volcanic context, especially in the form of dense swarms during eruptions. Mantle seismicity has been detected beneath Kilauea, Loihi ${ }^{41-}$ ${ }^{43}$ and La Réunion ${ }^{44}$ volcanoes, where it has been interpreted as failure of the brittle lithosphere induced by magma migration through long-lived tectonic structures or by the islands' loading.

The distribution of the seismicity in the first weeks of the crisis suggests a dyke migration from the mid-slope zone to the NVE, along the eastern segment of the Mayotte ridge. This is supported by the migration of the Centroid Moment Tensor solutions depths (CMT project) of the largest earthquakes towards the surface (extended data Figures $6 c$ and 8) and agrees well with ${ }^{45,2}$. The earthquakes show strike-slip focal mechanisms compatible with a least compressive principal stress orthogonal to the eastern segment of the ridge (extended data Figure 8). Similar stress trends have been observed during dyking events beneath the Izu peninsula in Japan ${ }^{46,47}$ and in Iceland ${ }^{48}$ but at much shallower depths, where they were interpreted as seismic shear faulting caused by stress transfer to the surrounding vertical faults in response to dyke opening and propagation ${ }^{46,47,48,49}$. 
During the first six weeks of the crisis, the magma migrated $20 \mathrm{~km}$ laterally along the eastern segment of the Mayotte ridge, then upward (Figure 4 and extended data Figure 8). The building of the NVE may have begun in July 2018 once the dyke reached close to the surface ${ }^{2,1}$ allowing for high magma flow rates and rapid ensuing growth. On the basis of this assumption, we estimate a minimum mean lava flow rate of $\sim 180 \mathrm{~m}^{3} \mathrm{~s}^{1}$ between the start of the eruption on the seafloor and our survey ( 11 months). The local stress probably decreased considerably once the magma path to the NVE was opened, as is observed during many eruptions involving dyke propagation ${ }^{50}$, which would explain why no earthquakes were detected beneath the NVE during the OBS deployment, which started in late February 2019. After the dike reached the near surface, seismicity resumed beneath the mid- and upper-slope volcanic zones (Figure 4 and extended data Figures 6a,b and 8) and its pattern appears to be constant since September $2018^{2}$. This stationary seismicity could be caused by stress perturbation along pre-existing structures and/or fluid (gas, magma or water) motions. The swarm 1 earthquakes cluster beneath a $10 \mathrm{~km}$-wide circular area that coincides with the ancient caldera structure inferred from our high-resolution bathymetry (Figure $1 c$ and extended data Figure $6 b$ and 8). This seismicity could indicate activation of pre-existing subvertical faults ${ }^{51}$ above a deep $(>55 \mathrm{~km})$ depleting reservoir $(\mathrm{R} 1,4)$, as has been observed during caldera collapse events ${ }^{52,53,54}$ but these faults would be much deeper than at any caldera structures documented elsewhere. Analog models for collapse of a caldera with a high-roof aspect ratio (thickness/width $>>1$ ) indicate_reverse fault motions during an initial downsag stage ${ }^{55}$, in accord with the focal mechanism of the May 14, 2019 Mw4.9 swarm 1 region earthquake (Figure 4 and extended data Figure 8) and ${ }^{45}$.

The VLF events, located above swarm1, may be generated by the resonance of a fluid-filled (magma, gas or hydrothermal) shallower cavity or a fluid-filled crack, most probably at the base of the crust. The characteristic frequency and duration of these events are very different 
from VLF events typically observed in volcanic zones ${ }^{56,57,58,59,60,61}$. Simple up-scaling of fluid resonance models ${ }^{62,63}$ imply a size of several kilometres for this shallower reservoir (R3, Figure 4). The excitation mechanism could be rapid slip and related strain on faults close to the reservoir or episodic collapse of a piston at the base of this shallow reservoir ${ }^{64}$. The acoustic plumes emanating from the overlying Horseshoe edifice may result from actively degassing of this shallower reservoir.

Both the distribution of seismicity over time and the surface deformation models suggest the drainage of an exceptionally deep reservoir by a dyke that propagated from the base of the brittle lithosphere to the eastern portion of the Mayotte ridge, possibly intersecting another vertical storage zone below seismic swarm 2 before reaching the surface (R2, Figure 4 and extended data Figure 9). Within the uncertainties the GNSS isotropic model may reflect the drainage of this reservoir R2 in the brittle lithosphere. The deeper reservoir R1 may have slowly recharged from the asthenosphere before reaching tensile failure in May $2018{ }^{65}$.

\section{Magma roots and paths.}

The eastern segment of the Mayotte ridge, along which the dike propagated, has the same orientation as many other volcanic features over a range of scales (quaternary dykes, volcanic vent alignments, ridges and volcanic rift zones) in the northeastern part of Mayotte Island ${ }^{15}$ and in and around the other Comoros islands ${ }^{13,66,14}$ (Figure 5 and extended data Figure 9). The left-lateral en-echelon arrangement of these features resembles that of extensional tectonic structures in a context of oblique extension (i.e in segmented and diffuse strike-slip fault systems ${ }^{67}$ or highly-oblique rifting ${ }^{68,69,70,71}$. We infer that the Mayotte ridge results from the interplay between volcanism and tectonics. The location and orientation of the volcanic features may be in part controlled by the pre-existing Mesozoic fracture zones ${ }^{6}$ but they probably also emplace along new tectonic structures. These tectonic structures are extensional (fissures or step-overs) and open as a result of volcano-tectonic interactions in a wide E-W 
striking zone, to transfer the strain between the N-S striking offshore branches of the East African rift ${ }^{72}$ and the grabens of Madagascar (Aloatra and Ankai) ${ }^{73,74}$. In this context, high strain rates ${ }^{69}$ or highly damaged zones may develop ${ }^{75}$ (Figure 5 a inset) in between the main en-echelon extensional structures. Such zones may constitute high-permeability zones where large magmatic reservoirs can develop. The main Comoros volcanic islands may have grown above such zones.

Between Mayotte and Madagascar, the lithosphere-asthenosphere boundary (LAB) is a sharp limit between a high-velocity $150 \mathrm{Ma}$ lithosphere and a low-velocity asthenosphere, at about $70 \mathrm{~km}$ depth ${ }^{76,77}$. The low-velocity asthenosphere is interpreted as hot material spreading beneath the Mascarene basin and beyond ${ }^{78}$. Heating of the base of the oceanic lithosphere damaged by extensional tectonic and loaded by Mayotte island ${ }^{79}$ may favour the ponding and withdrawal of large volumes of buoyant melts. Pore pressure increase in these zones may in turn favour failure of deep reservoirs and faults inside the brittle lithosphere

\section{The largest eruption ever documented in submarine domain}

The NVE extruded volume (as of May 2019) is 30 to 1000 times larger than that reported for other deep-sea eruptions ${ }^{21,26,27,80,81}$. As is the case for many submarine eruptions, it is difficult to evaluate the dense rock equivalent (DRE) volume ${ }^{20}$. Taking an upper bound of $50 \%$ for the DRE factor ${ }^{82}$, compatible with the $40 \%$ vesicularity of our sample ${ }^{28}$, the DRE erupted volume could be as large as $2.5 \mathrm{~km}^{3}$, which is larger than the 1.2 to $1.5 \mathrm{~km}^{3}$ Havre silicic eruption ${ }^{83,84}$, up to now considered to be the largest documented submarine eruption. It would be 2.5 times larger than the Bardabunga eruption (Iceland's largest eruption of the last two centuries) ${ }^{50,85}$ and only 6 times less than Iceland's 1783-1784 Laki eruption, considered to be one of the largest basaltic eruptions witnessed by humanity ${ }^{86}$. The volumes and flux of emitted lava during the Mayotte magmatic event are comparable to those observed during eruptions at Earth's largest hot spots (Hawaii, Iceland, ${ }^{50,87}$ and one quarter of that emplaced 
yearly over the entire mid-ocean ridge system (mean estimate from spreading rates over the last $80 \mathrm{Ma}^{88}$ ). It thus represents a considerable input in terms of $\mathrm{CO} 2 \mathrm{flux}^{89}$.

Future scenarios could include a new caldera collapse, submarine eruptions on the upper slope, or onshore eruptions. Large lava flows and cones on the upper slope and onshore Mayotte indicate that this has occurred in the past. Since the discovery of the NVE, an observatory has been established to monitor activity in real time (REVOSIMA ${ }^{90}$ ) and return cruises are ongoing to follow the evolution of the eruption and edifices.

\section{Acknowledgements}

We thank captain A. Eyssautier and the officers and the crew of the R/V Marion Dufresne (TAAF/IFREMER/LDA), GENAVIR's coordinator, M. Boudou D'hautefeuille, and the shipboard operations engineers. We thank the captain and crew of the M/V Ylang (SGTM company). We thank the French Ministries of Environment, Research and Overseas, CNRS/INSU, IPGP, IFREMER, BRGM and the Prefect of Mayotte for funding and support.

We thank our colleagues F. Tronel, A. Roulle, E. Dectot, A. Colombain, C. Doubre, Daniel Sauter, Antony Dofal and Antoine Villié for assistance in the field, previous data acquisition, processing and model development. We thank Olivier Desprez de Gesincourt, L. Testut and T. Tranchant for loan and data processing of the seafloor pressure sensors. We thank the French National Marine Hydrographic and Oceanographic Service (SHOM) for providing us with previous data from the area. We thank G. Barruol for discussions. This is IPGP contribution number XXXX.

\section{Method Summary}

Ship-borne Multibeam data was acquired using a Kongsberg EM122 $1^{\circ} \times 1^{\circ}$ during the 2014 ${ }^{19}$ and $2019^{18}$ cruises. Both data sets were processed with the GLOBE software ${ }^{91}$ to provide 
30-m grid spaced digital terrain models and seafloor backscatter imagery and to calculate depth differences, surface and volumes. The 3D acoustic water column data from the 2019 cruise were processed using SonarScope (@Ifremer) and GLOBE softwares ${ }^{91}$. Water column measurements: A CTD-Rosette Seabird 911+ CTD (Conductivity; Temperature; Depth) equipped with an altimeter, an Aanderaa oxygen optode and a Seapoint Turbidity Meter was mounted on a carousel with $16{ }^{\circledR N}$ Niskin sampling bottles (8L) to measure and sample throughout the water column. Sub-sampling was performed for onboard analyses $(\mathrm{pH}$, alkalinity and total $\mathrm{CO} 2$ by $\mathrm{pH}$ electrode and titrator) and for onshore analyses (CH4 analysis by the purge and trap method and $\mathrm{H} 2$ and $\mathrm{CO} 2$ analysis by the Headspace method). Seismology: 800 earthquakes identified from the onshore catalog were selected in descending magnitude order and manually picked onboard. The seismic network used during the two month deployment included OBSs, onshore local and regional stations (up to $500 \mathrm{~km}$ distance). The events were relocated with NonLinLoc ${ }^{92}$ and an hybrid velocity model based on trials with 6 different velocity models, achieving final location accuracies better than $5 \mathrm{~km}$. Eighty-four very low frequency (VLF) earthquakes were detected between February 25 and April 24, 2019, using an amplitude trigger on ocean bottom hydrophones recordings, filtered between 0.05 and $0.10 \mathrm{~Hz}$, followed by a selection of events with a clear peak frequency and a final visual inspection. VLF earthquakes were located using spatial 3D back-projection of station-pair cross-correlation functions ${ }^{93}$, assuming a constant surface-wave speed of 3.5 $\mathrm{km} / \mathrm{s}$. A well-constrained epicentral location was obtained for 81 events. Geodesy: We inverted the surface deformation recorded by 6 permanent GNSS (Global Navigation Satellite System) receivers installed in Mayotte, Grande Glorieuse and Madagascar. We used both an isotropic model and a triple volumetric discontinuities ( $\mathrm{pCDM}$ source) in a homogeneous elastic half-space, isotropic material with Poisson's ratio of 0.25 to model the pressure source in depth. Seafloor pressure data (30s sample interval) were pre-processed using harmonic 
analysis to remove the tides and low-pass filtering to remove residual oscillations interpreted as internal waves.

\section{Author contributions}

NF, SJ, WC, CD, IT, EJ, JMS, ALe, FP, RD, AG, CA, OF, PK, ALa, JPD, LG, JG, VG, PP, ER participated on the MAYOBS1 cruise (NF, SJ and WC as PI), acquired and processed the geophysical and seismological data. CSa, ALa and PB detected and located the VLF events. AP was in charge of the GNSS installation in Glorieuse island and processed and modeled the GNSS data with FB and RG. VB was in charge of the OBSs APGs and processed their data. SB participated in the first OBS deployment on the Ylang vessel with WC and RD. DB, ALM and JVW were responsible for the installation of new seismological and GNSS stations in Mayotte and of data acquisition onshore. JPD, VG, ER, CC performed the geochemical analysis and interpretation of the water column data. CSc and AG processed the EM122 acoustic data. CD and AG performed the depth changes calculation. CSc provided the interpretation of the water column acoustic data. PBa and YF furnished the rocks sample descriptions and petrological analysis. NF, SJ, CD, PBa, YF, IT, FP, JVW, EJ provided the geological interpretation.. NF wrote the paper with the contribution of all other authors. JMS, EJ, CSa, ALe, GL, CA, VB, AG, AP, FB, RG, ER, CC, CSc wrote the supplementary method and method online.

\section{Data availability statement}

The authors declare that most of the data supporting the findings of this study are available within the paper and its supplementary information files. GNSS data are available on the website «http://mayotte.gnss.fr ». Ship-borne geophysical data from the MAYOBS1 cruise can be obtained through the French national oceanographic data center SISMER (http://en.data.ifremer.fr/SISMER) but restrictions apply to the availability of these data. The 

(http://www.shom.fr.) 


\section{REFERENCES}

1 Cesca, S. et al. Drainage of a deep magma reservoir near Mayotte inferred from seismicity and deformation. Nat. Geosci. 13, 87-93, doi:10.1038/s41561-019-0505-5 (2020).

Lemoine, A., Bertil, D., Roullé, A. \& Briole, P. The volcano-tectonic crisis of 2018 east of Mayotte, Comoros islands. Geophys. J. Int.

REVOSIMA, R. d. s. V. e. S. d. M. REVOSIMA (2020), Bulletin nº 18 de l'activité sismo-volcanique à Mayotte, du 1 au 31 août, . Report No. 2680-1205, (2020). U.S. Geological Survey. (https://earthquake.usgs.gov/earthquakes/search 2019).

5 Zinke, J., Reijmer, J. \& Thomassin, B. Systems tracts sedimentology in the lagoon of Mayotte associated with the Holocene transgression. Sedimentary Geology 160, 57-79 (2003).

Phethean, J. J. et al. Madagascar's escape from A frica: A high - resolution plate reconstruction for the W estern S omali B asin and implications for supercontinent dispersal. Geochemistry, Geophysics, Geosystems 17, 5036-5055 (2016). Pelleter, A.-A. et al. Melilite-bearing lavas in Mayotte (France): An insight into the mantle source below the Comores. Lithos 208-209, 281-297, doi:10.1016/j.lithos.2014.09.012 (2014). Class, C., Goldstein, S. L., Altherr, R. \& Bachèlery, P. The process of plume-lithosphere interactions in the ocean basins - the case of Grande Comore. Journal of Petrology 39, 881-903 (1998). Claude-Ivanaj, C., Bourdon, B. \& Allègre, C. J. Ra-Th-Sr isotope systematics in Grande Comore Island: a case study of plume-lithosphere interaction. Earth and Planetary Science Letters 164, 99-117 (1998). Ebinger, C. J. \& Sleep, N. Cenozoic magmatism throughout east Africa resulting from impact of a single plume. Nature 395, 788-791 (1998).

Reiss, M., Long, M. \& Creasy, N. Lowermost mantle anisotropy beneath Africa from differential SKS - SKKS shear - wave splitting. Journal of Geophysical Research: Solid Earth 124, 8540-8564 (2019). Class, C., Goldstein, S. L., Stute, M., Kurz, M. D. \& Schlosser, P. Grand Comore Island: A wellconstrained "low 3He/4He" mantle plume. Earth and Planetary Science Letters 233, 391-409 (2005). Nougier, J., Cantagrel, J. \& Karche, J. The Comores archipelago in the western Indian Ocean: volcanology, geochronology and geodynamic setting. J. Afr. Earth Sci. (1983) 5, 135-145 (1986). Famin, V., Michon, L. \& Bourhane, A. The Comoros archipelago: a right-lateral transform boundary between the Somalia and Lwandle plates. Tectonophysics 789, 228539 (2020). Nehlig, P. et al. Report French geological map (1/30 000), sheet Mayotte (1179). Orléans: BRGM, 74 p. . Geological map by Lacquement F., Nehlig P, Bernard J. (2013). (2013). Audru, J.-C., Guennoc, P., Thinon, I. \& Abellard, O. Bathymay : la structure sous-marine de Mayotte révélée par l'imagerie multifaisceaux. Comptes Rendus Geoscience 338, 1240-1249, doi:10.1016/j.crte.2006.07.010 (2006). Senjuan, B. et al. Estimation du potentiel géothermique de Mayotte : Phase 2 - Etape 2. Investigations géologiques, géochimiques et géophysiques complémentaires, synthèse des résultats. 82 (BRGM, Orléans, France, 2008).

Feuillet, N. MAYOBS1 French Oceanographic cruise, RV Marion Dufresne. doi:https://doi.org/10.17600/18001217 (2019).

SHOM. (2014).

Rubin, K. H. et al. Volcanic eruptions in the deep sea. Oceanography 25, 142-157 (2012). Chadwick Jr, W. W. et al. Recent eruptions between 2012-2018 discovered at West Mata submarine volcano (NE Lau Basin, SW Pacific) and characterized by new ship, AUV, and ROV data. Frontiers in Marine Science 6, 495 (2019).

Clague, D. A. et al. Structure of Lō'ihi Seamount, Hawai'i, and Lava Flow Morphology from Highresolution Mapping. Frontiers in Earth Science 7, 58 (2019).

Cole, J., Milner, D. \& Spinks, K. Calderas and caldera structures: a review. Earth-Science Reviews 69, 1-26 (2005). investigation of the hydrothermal complex of Masaya volcano, Nicaragua. Journal of Volcanology and Geothermal Research 227, 15-31 (2012).

Yeo, I. A. \& Searle, R. High - resolution Remotely Operated Vehicle (ROV) mapping of a slow spreading ridge: Mid - Atlantic Ridge 45 $\quad$ N. Geochemistry, Geophysics, Geosystems 14, 1693-1702 (2013). Seamount in April 2011. Nature Geosci 5, 483-488, doi:10.1038/ngeo1496 (2012). 

lava flows at Axial Seamount. Oceanography 30, 82-99 (2017). Mayotte Eruption: First Results. AGUFM 2019, V52D-06 (2019). Cathalot, C. et al. Acoustic and Geochemical Anomalies in the Water Column around the Newly Formed Volcano offshore Mayotte Island. AGUFM 2019, V52D-05 (2019). Resing, J. A. et al. Active submarine eruption of boninite in the northeastern Lau Basin. Nature Geoscience 4, 799-806 (2011).

31 Baumberger, T. et al. Understanding a submarine eruption through time series hydrothermal plume sampling of dissolved and particulate constituents: W est M ata, 2008-2012. Geochemistry, Geophysics, Geosystems 15, 4631-4650 (2014). response, and new technology. Oceanography 25, 128-141 (2012).

Chadwick, W. W. et al. Imaging of $\mathrm{CO} 2$ bubble plumes above an erupting submarine volcano, NW Rota - 1, Mariana Arc. Geochemistry, Geophysics, Geosystems 15, 4325-4342 (2014).

4 Somoza, L. et al. Evolution of submarine eruptive activity during the 2011-2012 E $1 \mathrm{H}$ ierro event as documented by hydroacoustic images and remotely operated vehicle observations. Geochemistry, Geophysics, Geosystems 18, 3109-3137 (2017).

Sohn, R. A. et al. Explosive volcanism on the ultraslow-spreading Gakkel ridge, Arctic Ocean. Nature 453, 1236-1238 (2008).

Barreyre, T., Soule, S. A. \& Sohn, R. A. Dispersal of volcaniclasts during deep-sea eruptions: Settling velocities and entrainment in buoyant seawater plumes. Journal of Volcanology and Geothermal Research 205, 84-93 (2011).

7 Tarantola, A. Linearized inversion of seismic reflection data. Geophysical prospecting 32, 998-1015 (1984).

Anderson, E. Dynamics of formation of cone-sheets, ring-dikes, and cauldron subsidences: Royal Society of Edinburgh Proceedings, v. 56. (1936).

Nikkhoo, M., Walter, T. R., Lundgren, P. R. \& Prats-Iraola, P. Compound dislocation models (CDMs) for volcano deformation analyses. Geophysical Journal International, ggw427 (2016).

Dofal, A., Fontaine, F. R., Michon, L., Barruol, G. \& Tkalcic, H. in AGU Fall Meeting 2018. (AGU). Wolfe, C. J., Okubo, P. G. \& Shearer, P. M. Mantle fault zone beneath Kilauea volcano, Hawaii. Science 300, 478-480 (2003).

Wright, T. L. \& Klein, F. W. Deep magma transport at Kilauea volcano, Hawaii. Lithos 87, 50-79, doi:10.1016/j.lithos.2005.05.004 (2006).

Merz, D., Caplan - Auerbach, J. \& Thurber, C. Seismicity and Velocity Structure of Lō'ihi Submarine Volcano and Southeastern Hawai'i. Journal of Geophysical Research: Solid Earth 124, 11380-11393 (2019).

Michon, L., Ferrazzini, V., Di Muro, A., Villeneuve, N. \& Famin, V. Rift zones and magma plumbing system of Piton de la Fournaise volcano: How do they differ from Hawaii and Etna. J. Volc. Geotherm. Res. 303, 112-129, doi:10.1016/j.jvolgeores.2015.07.031 (2015). Cesca, S. et al. Very long period signals and seismic swarm activity offshore Mayotte, Comoro Islands. (2019).

Toda, S., Stein, R. \& Sagiya, T. Evidence from the AD 2000 Izu islands earthquake swarm that stressing rate governs seismicity. Nature 419, 58-61, doi:10.1038/nature00997 (2002). Hayashi, Y. \& Morita, Y. An image of a magma intrusion process inferred from precise hypocentral migrations of the earthquake swarm east of the Izu Peninsula. Geophysical Journal International 153, 159-174 (2003).

8 Ágústsdóttir, T. et al. Strike - slip faulting during the 2014 Bárðarbunga - Holuhraun dike intrusion, central Iceland. Geophysical Research Letters 43, 1495-1503 (2016).

Ukawa, M. \& Tsukahara, H. Earthquake swarms and dike intrusions off the east coast of Izu Peninsula, central Japan. Tectonophysics 253, 285-303 (1996).

Sigmundsson, F. et al. Segmented lateral dyke growth in a rifting event at Bárðarbunga volcanic system, Iceland. Nature 517, 191-195, doi:10.1038/nature14111 (2015).

Jacques, E. et al. in $A G U$ (Online everywhere, 2020).

Filson, J., Simkin, T. \& Leu, L. k. Seismicity of a caldera collapse: Galapagos Islands 1968. Journal of Geophysical Research 78, 8591-8622 (1973).

53 Geshi, N. \& Oikawa, T. Phreatomagmatic eruptions associated with the caldera collapse during the Miyakejima 2000 eruption, Japan. Journal of volcanology and geothermal research 176, 457-468 (2008). 
Gudmundsson, M. T. et al. Gradual caldera collapse at Bárdarbunga volcano, Iceland, regulated by lateral magma outflow. Science 353, aaf8988 (2016). Roche, O., Druitt, T. \& Merle, O. Experimental study of caldera formation. Journal of Geophysical Research: Solid Earth 105, 395-416 (2000).

56 Kumagai, H. \& Chouet, B. A. Acoustic properties of a crack containing magmatic or hydrothermal fluids. Journal of Geophysical Research: Solid Earth 105, 25493-25512 (2000). Woods, J. et al. Long-period seismicity reveals magma pathways above a laterally propagating dyke during the 2014-15 Bárðarbunga rifting event, Iceland. Earth and planetary science letters 490, 216229 (2018).

58 Kumagai, H. et al. Magmatic dike resonances inferred from very-long-period seismic signals. Science 299, 2058-2061 (2003).

Kobayashi, T., Ohminato, T., Ida, Y. \& Fujita, E. Very long period seismic signals observed before the caldera formation with the 2000 Miyake - jima volcanic activity, Japan. Journal of Geophysical Research: Solid Earth 114 (2009).

60 Aster, R. et al. Very long period oscillations of Mount Erebus Volcano. Journal of Geophysical Research: Solid Earth 108 (2003).

61 Shuler, A. \& Ekström, G. Anomalous earthquakes associated with Nyiragongo Volcano: Observations and potential mechanisms. Journal of Volcanology and Geothermal Research 181, 219-230 (2009). Fazio, M., Alparone, S., Benson, P. M., Cannata, A. \& Vinciguerra, S. Genesis and mechanisms controlling tornillo seismo-volcanic events in volcanic areas. Scientific reports 9, 1-11 (2019). Maeda, Y. \& Kumagai, H. A generalized equation for the resonance frequencies of a fluid-filled crack. Geophysical Journal International 209, 192-201 (2017). Science 293, 687-690, doi:10.1126/science.1062136 (2001). Sigmundsson, F. et al. Unexpected large eruptions from buoyant magma bodies within viscoelastic crust. Nature Communications 11, 1-11 (2020).

66 Bachèlery, P. et al. in Active Volcanoes of the Southwest Indian Ocean 345-366 (Springer, 2016).

67 Armijo, R., Meyer, B., Navarro, S., King, G. \& Barka, A. Asymmetric slip partitioning in the Sea of Marmara pull - apart: A clue to propagation processes of the North Anatolian fault? Terra Nova 14, 8086 (2002).

68 Dauteuil, O. \& Brun, J.-P. Oblique rifting in a slow-spreading ridge. Nature 361, 145-148 (1993).

69 Brune, S. Evolution of stress and fault patterns in oblique rift systems: 3 - D numerical lithospheric scale experiments from rift to breakup. Geochemistry, Geophysics, Geosystems 15, 3392-3415 (2014). Corti, G. Evolution and characteristics of continental rifting: Analog modeling-inspired view and comparison with examples from the East African Rift System. Tectonophysics 522, 1-33 (2012). Pagli, C., Yun, S.-H., Ebinger, C., Keir, D. \& Wang, H. Strike-slip tectonics during rift linkage. Geology 47, 31-34 (2019). Franke, D. et al. The offshore East African Rift System: Structural framework at the toe of a juvenile rift. Tectonics 34, 2086-2104 (2015).

Rufer, D., Preusser, F., Schreurs, G., Gnos, E. \& Berger, A. Late Quaternary history of the Vakinankaratra volcanic field (central Madagascar): insights from luminescence dating of phreatomagmatic eruption deposits. Bulletin of volcanology 76, 817 (2014). Kusky, T. M., Toraman, E., Raharimahefa, T. \& Rasoazanamparany, C. Active tectonics of the Alaotra-Ankay Graben System, Madagascar: possible extension of Somalian-African diffusive plate boundary? Gondwana Research 18, 274-294 (2010). Peacock, D. \& Anderson, M. THE SCALING OF PULL - APARTS AND IMPLICATIONS FOR FLUID FLOW IN AREAS WITH STRIKE - SLIP FAULTS. Journal of Petroleum Geology 35, 389399 (2012).

76 Pratt, M. J. et al. Shear velocity structure of the crust and upper mantle of Madagascar derived from surface wave tomography. Earth and Planetary Science Letters 458, 405-417 (2017). Mazzullo, A. et al. Anisotropic Tomography Around La Réunion Island From Rayleigh Waves. J. Geophys. Res. Solid Earth 122, 9132-9148, doi:10.1002/2017JB014354 (2017).

78 Barruol, G. et al. Large-scale flow of Indian Ocean asthenosphere driven by Réunion plume. Nat. Geosci. 12, 1043-1049, doi:10.1038/s41561-019-0479-3 (2019).

79 Zhong, S. \& Watts, A. Lithospheric deformation induced by loading of the Hawaiian Islands and its implications for mantle rheology. Journal of Geophysical Research: Solid Earth 118, 6025-6048 (2013).

80 Watts, A. B. et al. Rapid rates of growth and collapse of Monowai submarine volcano in the Kermadec Arc. Nature Geosci 5, 510-515, doi:10.1038/ngeo1473 (2012). 

spreading center. Frontiers in Earth Science 6, 172 (2018). eruptions driven by volatile-coupled degassing at Lōihi Seamount, Hawaii. Earth and Planetary Science Letters 295, 497-510 (2010).

83 Carey, R. J., Wysoczanski, R., Wunderman, R. \& Jutzeler, M. Discovery of the largest historic silicic submarine eruption. Eos, Transactions American Geophysical Union 95, 157-159 (2014). Carey, R. et al. The largest deep-ocean silicic volcanic eruption of the past century. Science advances $\mathbf{4}$, e1701121 (2018).

85 Bonny, E., Thordarson, T., Wright, R., Höskuldsson, A. \& Jónsdóttir, I. The volume of lava erupted during the 2014 to 2015 eruption at Holuhraun, Iceland: A comparison between satellite - and ground - based measurements. Journal of Geophysical Research: Solid Earth 123, 5412-5426 (2018). Thordarson, T. \& Self, S. The Laki (Skaftár Fires) and Grímsvötn eruptions in 1783-1785 Bull Volcanol 55, 233-263 (1993). Neal, C. Cogné, J.-P. \& Humler, E. Temporal variation of oceanic spreading and crustal production rates during the last 180 My. Earth and Planetary Science Letters 227, 427-439 (2004). 145, 233-248 (1998). REVOSIMA, R. d. s. V. e. S. d. M. Bulletin n 16 de l'activité sismo-volcanique à Mayotte, du 1 au 31 mars 2020. (2020).

91 Globe (GLobal Oceanographic Bathymetry Explorer) Software. (2020).

92 Lomax, A., Michelini, A. \& Curtis, A. Earthquake location, direct, global-search methods. Encyclopedia of complexity and system science 5, 1-33 (2009).

93 Poiata, N., Satriano, C., Vilotte, J.-P., Bernard, P. \& Obara, K. Multiband array detection and location of seismic sources recorded by dense seismic networks. Geophysical Journal International 205, 15481573 (2016).

94 SHOM. (MNT_MAY100m_HOMONIM_WGS84, 2016).

95 JORRY, S. (2014).

96 Debeuf, D. Etude de l'évolution volcano-structurale et magmatique de Mayotte, Archipel des Comores, océan Indien: approches structurale, pétrographique, géochimique et géochronologique, (2009). Ekström, G., Nettles, M. \& Dziewoński, A. The global CMT project 2004-2010: Centroid-moment tensors for 13,017 earthquakes. Physics of the Earth and Planetary Interiors 200, 1-9 (2012). Stamps, D., Saria, E. \& Kreemer, C. A Geodetic Strain Rate Model for the East African Rift System. Sci, Rep, 8, 732, doi:10.1038/s41598-017-19097-w (2018). Mougenot, D., Hernandez, J. \& Virlogeux, P. Structure et volcanisme d'un rift sous-marin; le fosse des Kerimbas (marge nord-mozambique). Bulletin de la Société Géologique de France, 401-410 (1989). Deville, E. et al. Active fault system across the oceanic lithosphere of the Mozambique Channel: implications for the Nubia-Somalia southern plate boundary. Earth and Planetary Science Letters $\mathbf{5 0 2}$, 210-220 (2018).

Macgregor, D. History of the development of the East African Rift System: A series of interpreted maps through time. Journal of African Earth Sciences 101, 232-252 (2015). 


\section{FIGURE CAPTIONS}

Figure 1: The volcanic ridge offshore Mayotte. a) Westward view of Mayotte island and insular slope (vertical exaggeration 3) with MAYOBS1 cruise multibeam EM122 bathymetry (resolution: $30 \mathrm{~m}^{18}$ ) superimposed on a previous bathymetry-topography compilation ${ }^{16,94}$. The volcanic Mayotte ridge extends from the onshore Mamoudzou-Petite Terre volcanic zones to the new volcanic edifice (NVE). Green arrows and stars: location of acoustically-detected plumes above the Horseshoe, the NVE and the degassing area on Petite-Terre island. Left inset: geographic setting and surface horizontal displacements (with plate velocity removed) recorded by Global Navigation Satellite System (GNSS) stations in Mayotte, Grande Glorieuse and Madagascar (Diego Suarez). Black points: seismic stations (details and name in Supplementary material). Dashed grey lines: NNW-SSE to N-S striking Mesozoic fracture zones resulting from the Gondwana break-up ${ }^{6}$. b) MAYOBS1 multibeam bathymetry superimposed over slopes (dark zones: steep slopes) and geological interpretations. Volcanic structures are indicated in purple (mainly cones) and pink (lava flows and elongated features). In yellow: Upper slope's highly reflective patches (backscatter data). The NVE is indicated in red (central part with steep slopes) and orange (radial ridges and flat flows). Green stars: degassing areas detected acoustically (on the Horseshoe) and visually (on Petite-Terre) ${ }^{17}$. Red lines: fissures and faults, dashed lines for inferred faults. Area filled with small black dots: bathymetric depression. White boxes: location of Fig.2a and Extended data Fig. 3. Inset, as in b with Mayotte ridge segments underlined by red and purple colored patches, pink dots: seismicity recorded during the Ocean Bottom seismometer (OBS) deployment and relocated on board; yellow diamonds: location of the Very Low Frequency earthquakes c) MAYOBS1 multibeam backscatter map (white $=$ higher reflectivity). Shallow bathymetry and topography are the same as in a). Pink dots and yellow diamonds as in b) inset. Black and white boxes: location of extended data Figure 3, respectively.

Figure 2: The new volcanic edifice (NVE) offshore Mayotte. a) $30 \mathrm{~m}$ resolution bathymetric maps from shipboard EM122 multibeam, illuminated from N290 ${ }^{\circ}$. Left panel: SHOM bathymetry collected in $2014{ }^{19}$. Right panel: MAYOBS1 bathymetry collected in May $2019^{18}$. Red circle: position of dredge DR01. b) Depth changes between 2014 and 2019. The change in topography is estimated to be significant when larger than $10 \mathrm{~m}$. 
Figure 3: a) Southward 3D view of the NVE and the water column acoustic plume observed one hour before the Conductivity-Temperature-Depth (CTD) rosette on May 16th 2019 (White dot and blue patch) deployed, $1 \mathrm{~km}$ far from the summit the volcano (see Extended data Figure 4). Right inset: Processed polar echogram from one EM122 multibeam ping on May 16th (13:33 UT), horizontal and vertical-axes (both in meters) correspond respectively to the cross-track distance and the water depth. See also Acoustic plume movie 1.

Figure 4: Conceptual model of the submarine eruption offshore Mayotte eruption: Bathymetry as in Figure $1 \mathrm{~b}$, no vertical exaggeration. Red zones on the seafloor: $\mathrm{N} 130^{\circ} \mathrm{E}$ volcano-tectonic ridges (Jumelles ridges) and segments including Mayotte ridge eastern segment. Dashed white lines: inferred ancient caldera with degassing zones above. In crosssection: red and reddish zones: magma storage zones (mush or magma chambers) and magma pathways involved in the 2018-2020 Mayotte volcanic crisis and seafloor eruption. Yellow layer: sediments. Dashed lines: subvertical faults beneath inferred caldera possibly reactivated by the deflation of a deep reservoir. White arrow: possible downsag at an initial stage of caldera collapse. Pink dots: 800 earthquakes between 25 February and May 62019 located using OBSs and land stations. Other dots: 139 earthquakes from before the OBS deployment, picked on land stations and relocated using a new model based on the OBS+land data: colored dots are from the first 6 weeks of the crisis and white dots from the remaining 8 months before the OBS deployment. Yellow diamonds: Very Low Frequency (VLF) earthquakes, constrained by the OBS+land network. Blue and red triangles: water and magma movements, respectively. Blue patch: Location, with 3 sigma uncertainties, of the most robust isotropic source deformation model. Moho depth from ${ }^{40}$. Lithosphere/asthenosphere boundary depth from ${ }^{77,78}$.

Figure 5: Regional volcano-tectonic setting of the submarine eruption offshore Mayotte.

a) Volcano-tectonic setting of the new volcanic edifice (NVE). Bathymetry compiled from MAYOBS1 cruise ${ }^{18}$, PTOLEMEE Cruise ${ }^{95}$, and the General Bathymetric Chart of the Oceans (https://www.gebco.net). Global topography from SRTM GL1 
(https://catalog.data.gov/dataset/shuttle-radar-topography-mission-srtm-gl1-global-30m).

Volcanic cones and ridges (purple) from ${ }^{13,96,16,14}$ and this study. Dots and diamonds are earthquakes as in Figure 4 and Extended data Fig. 6 and 8. Beach balls: focal mechanisms for $\mathrm{M}>5$ earthquakes ${ }^{97}$. Dotted white arrow: dyking event along the N130 $\mathrm{E}$ trending eastern segment of the Mayotte volcanic ridge. Red ellipse: inferred main volcano-tectonic ridges (Mayotte, Jumelles...). Purple ellipses: highly damaged zones in between the en echelon ridges (see sandbox model in Inset). Thick black arrows: local extension direction. Inset: sandbox model from ${ }^{75}$ illustrating the possible arrangement of the main volcano-tectonic structures in Comoros (see also Extended data Figure 9). b) Geodynamic setting of the East African Rift systems. Bathymetry from GeoMapApp (www.geomapapp.org), main tectonic structures and extensional zones in Africa and Madagascar adapted from ${ }^{98,73,74,99,100,101,72}$ and references therein. Purple patches: Quaternary volcanism in Madagascar from ${ }^{73}$. Red dots: $M>2.5$ earthquakes ${ }^{4}$ with focal mechanisms from the Global Centroid-Moment-Tensor Project ${ }^{97}$ for the $\mathrm{M}>5$ earthquakes. Arrows: GNSS horizontal motions ${ }^{98}$. Small purple ellipses in the Comoros as in a) with double dark red arrows: the volcanic ridge east of Mayotte and extension direction. Inset: Simplified tectonic map of the East African Rift system: Yellow highlights: most active rifts and grabens; Red ellipse: Transfer zone of the Comoros with direction of lateral motion. 
Extended data. Figure 1: 3-D westward view of submarine volcanic features located east of Mayotte, 3x vertical exaggeration. Bathymetry from MAYOBS1 30-m resolution DTM and previous bathymetry-topography compilation ${ }^{16,94}$ a) bathymetry (b) Backscatter seafloor reflectivity (white is highest reflectivity) from MAYOBS1 cruise.

Extended data. Figure 2: Volcanic features offshore Mayotte. a) 30-m resolution EM122 multibeam bathymetry (MAYOBS 1 cruise) superimposed on a previous bathymetrytopography compilation ${ }^{16,94}$ with locations of Fig2.b,c,d indicated. b), c) Interpreted MAYOBS1 shipboard bathymetry and backscatter of the upper slope east of Mayotte (location in a). Cones, lava flows and canyons as in Figure 1b. Black dots: bathymetric depression. Dashed red lines: possible pre-existing caldera structure. d) Interpreted bathymetry of the lower slope east of Mayotte (localisation in a). e) zoom on d) showing monogenetic cones and lava flows

Extended data. Figure 3: New volcanic edifice. a) 2014 EM122 multibeam seafloor backscatter ${ }^{19}$. b) 2019 reflectivity (MAYOBS 1 cruise) ${ }^{18}$. c) Depth changes between the 2014 and 2019 surveys, superimposed on 2019 reflectivity. The white areas of the 2019 backscatter map exceeding the bathymetric difference map indicate the extent of new volcanic material.

Extended data. Figure 4: CTD (conductivity temperature-depth)-Rosette measurements. a) Nephelometry and b) temperature vertical profiles. c)-g) sample analyses from 8L ®Niskin bottles. c)-e) Gas concentrations $\left(\mathrm{CH}_{4}, \mathrm{H}_{2}, \mathrm{CO}_{2}\right)$;.f) $\left.\mathrm{pH}, \mathrm{g}\right)$ total alkalinity and total $\mathrm{CO} 2$.

Extended data. Figure 5: Acoustic plumes over the Horseshoe volcanic structure. a) Southward 3D view of the horseshoe morphology and two water column acoustic plumes observed on the western internal flank. b) Processed polar echogram from one EM122 multibeam ping of the data set displayed in (a) acquired on May 18th (0541 UT) horizontal and vertical-axes correspond respectively to the cross-track distance and the water depth, in meters) - see also Acoustic plume movie 2. 
Extended data. Figure 6: Top: map views, bottom: cross-sections (A-A') projection along azimuth $\mathrm{N} 115^{\circ} \mathrm{E}$; (B-B') along azimuth $\mathrm{N} 45^{\circ} \mathrm{E}$. a) Earthquakes recorded by onshore seismological stations before the deployment of the Ocean bottom seismometers (OBS). Colored circles are events occuring in the first six weeks of the crisis, white circles are earthquakes in the intervening 8 months. b) Earthquakes recorded by the OBS+land stations between February 25 and May 62019 (pink dots). Yellow diamonds: location of the Very Low Frequency (VLF) events located in this study (see supplementary information). c) Focal mechanisms of the largest earthquakes from the Harvard CMT catalog (https://www.globalcmt.org/), with color scale as in a).

Extended data. Figure 7 - Global Navigation Satellite System (GNSS) data modelling and seafloor subsidence estimated from seafloor pressure variations. a) Map shows the locations of the stations used. Arrows with colors with names: GNSS velocity vectors $(\mathrm{mm} / \mathrm{yr})$ and station names. Coloured numbers: vertical deformation $(\mathrm{mm} / \mathrm{yr})$. Inset: yellow dots locate pressure sensors on ocean bottom seismometer stations (see Fig.S2.1 for names), red arrows: Mayotte GNSS velocity vectors ( $\mathrm{mm} / \mathrm{yr}$ ), white arrows: far field GNSS velocity vectors. b) GNSS Time series with relative displacements recorded on the east (top), north (middle) and vertical (bottom) components of the stations between January 2018 and January 2020. c) Best fit-models with $1 \sigma$ uncertainties of the GNSS data for one isotropic point source and a triple volumetric discontinuity pCDM source. d) Top panel: Pressure recorded by Seabird SBE37 gauges at the six ocean-bottom seismometer stations (Yellow dots inset Figure $7 \mathrm{a}$ and Fig. S2.1) de-tided and converted to vertical motion.Middle panel: vertical deformation estimated at each seafloor instrument location, using the best isotropic source model obtained from the GNSS data for the March 1st to May 1st 2019 period. Lower panel: residual signal after subtracting the model-predicted trend from the seafloor pressure variations. This residual probably contains instrumental drift (especially in the first 2 weeks of the deployment) but may also include some mis-modelled seafloor deformation. The residuals at stations MOSE and MONE (see location on Figure S2.1) exhibit slight negative and positive trends, respectively which could indicate that the volcanic source is located a bit further south than that modelled using the GNSS data, assuming that instrumental drift is not the dominant factor. 
Extended data. Figure 8: Conceptual model for the Mayotte seismo-volcanic event. Circles and diamonds are events as in Extended data - Figure 6. Focal mechanisms of main earthquakes are from Harvard CMT catalog (https://www.globalcmt.org/ ${ }^{97}$ ) with the same color scale as the May 10 to June 30, 2018 events, Yellow circle and blue patch: Location, with 3 sigma uncertainties, of the most robust isotropic source deformation model. a) Map view: The redish ellipse: Mayotte ridge, dashed circular area: old caldera structure in the morphology b) Cross-section (projection along azimuth 115 degree). Symbols as in a). Red lines: magma migration (dykes). Red ellipses and circle: magma reservoirs or mushes. Pink arrow: possible downsag along caldera structures. Redish zone: Eastern segment of the Mayotte ridge.

\section{Extended data. Figure 9: Regional volcano-tectonic setting of the submarine eruption} offshore Mayotte. a) Volcano-tectonic setting of the new volcanic edifice (NVE). Bathymetry compiled from MAYOBS1 cruise ${ }^{18}$, PTOLEMEE cruise ${ }^{95}$, and the General Bathymetric Chart of the Oceans (https://www.gebco.net). Global topography from SRTM GL1 (https://catalog.data.gov/dataset/shuttle-radar-topography-mission-srtm-gl1-global-30m). Volcanic cones and ridges (purple) from ${ }^{13,96,16,14}$ and this study. Beach balls: focal mechanisms for $\mathrm{M}>5$ earthquakes ${ }^{97}$. Dotted white arrow: dyking event along the $\mathrm{N} 130^{\circ} \mathrm{E}$ trending eastern segment of the volcanic ridge. Pink ellipse: inferred main volcano-tectonic ridges. Purple ellipses: highly damaged zones in between the en-echelon ridges (see sand box model Inset of Figure 5). Thick black arrows: local extension direction. 


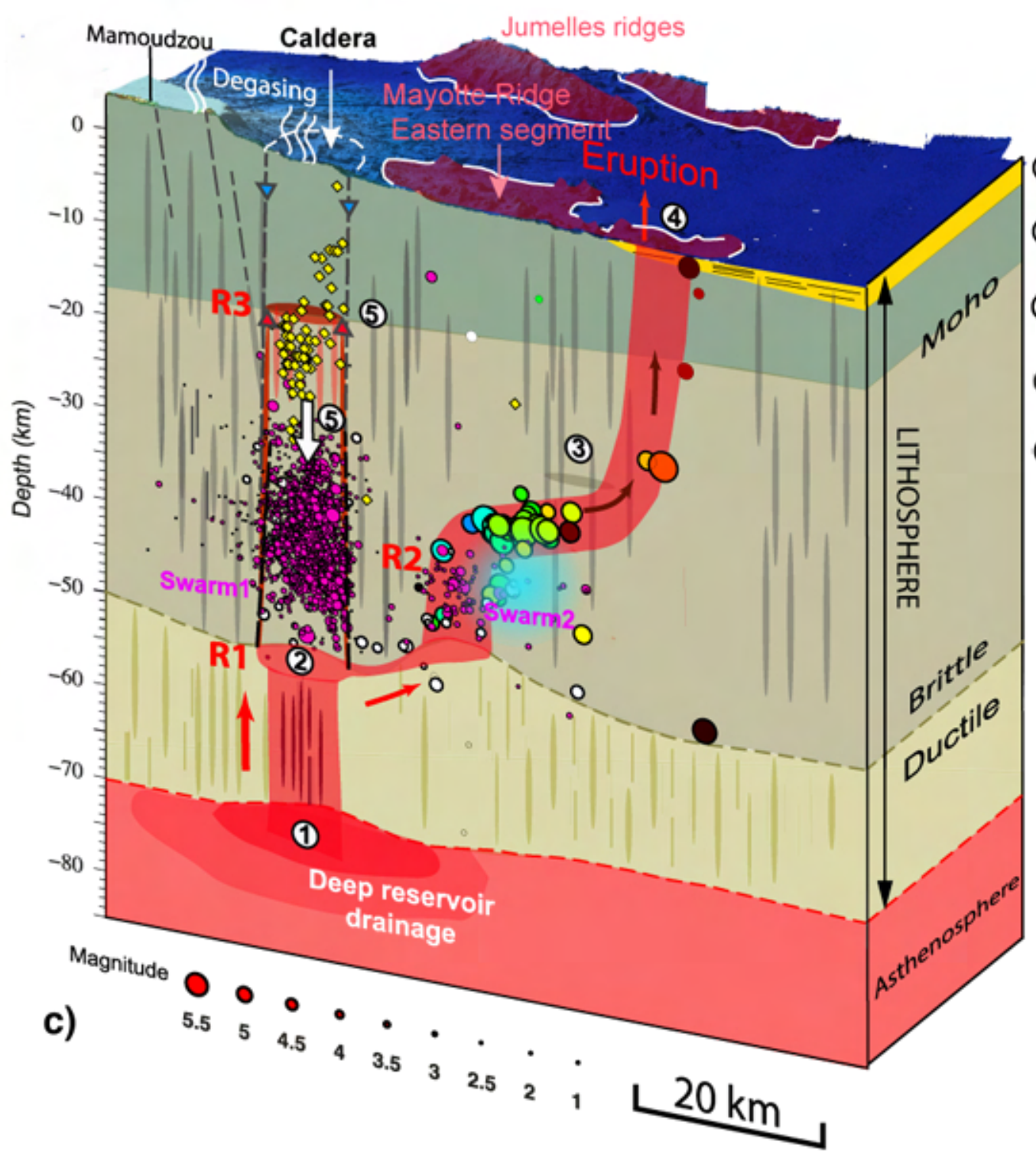

\section{Chronology}

(1) Deep asthenospheric reservoir drainage (before May 10 2018)

(2) slow refilling of the deep reservoir (before May 10 2018)

(3) Reservoir failure/Dyking (May-June 2018)

(4) Start of the eruption (July 2018) lithospheric reservoirs drainage

(5) Reactivation of faults beneath ancient caldera ? (Sept 2018)

+ Fluid movement (magma/water)?

\section{Seismicity time scale}

MAYOBSI data (26/02/19 - 6/05/2019)

VT $\diamond$ VLF

Before OBS deployment

O $07 / 18-02 / 19$

$28 / 06 / 2018$

$21 / 06 / 2018$

$14 / 06 / 2018$

$07 / 06 / 2018$

$31 / 05 / 2018$

$24 / 05 / 2018$

17/05/2018

Figure 4 


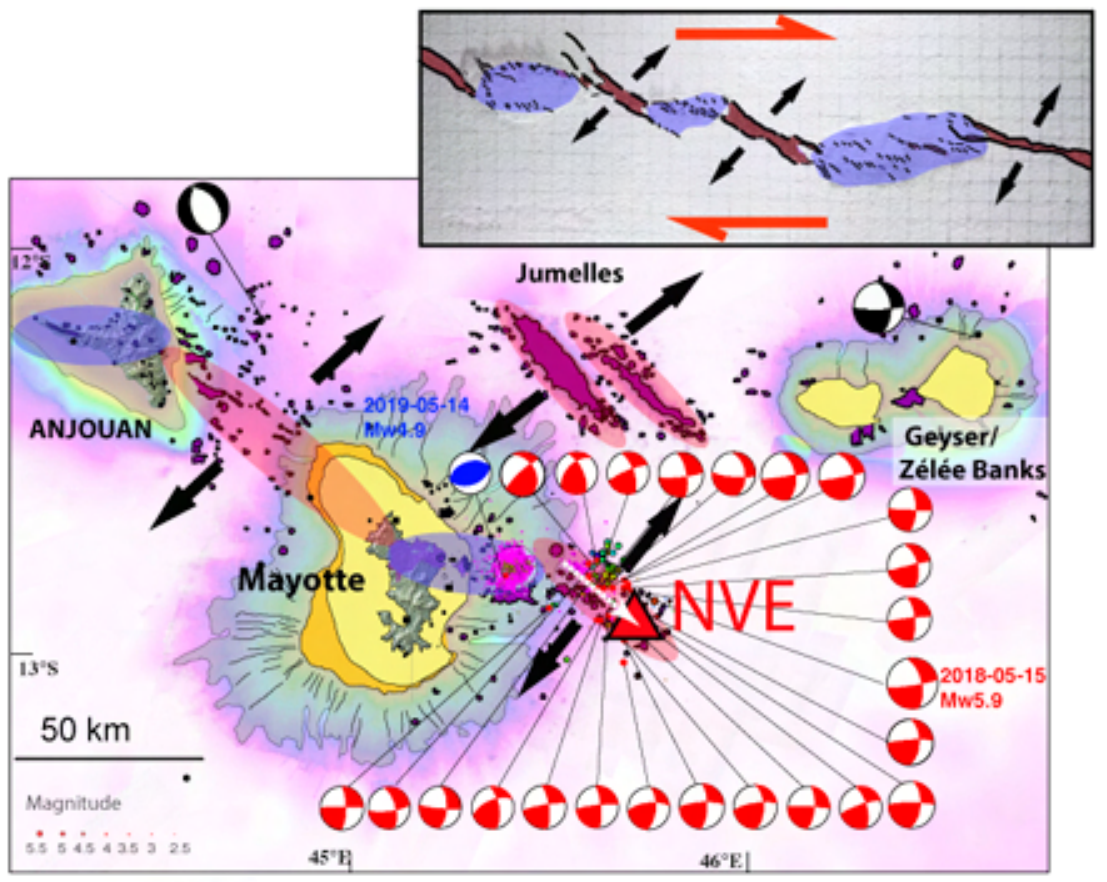

a)

$$
\begin{aligned}
& 0^{0 \text { Depth }(m)-3600} \\
& \text { Magnitude } \begin{array}{l}
0 \\
\hline
\end{array}
\end{aligned}
$$$$
\because 8
$$

5

1:

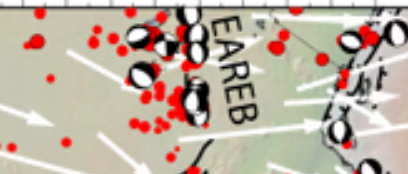

- 950.

9280

te

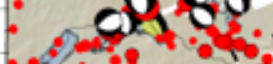

$$
\text { . }
$$

$$
\text { s }
$$$$
\frac{1}{2}
$$
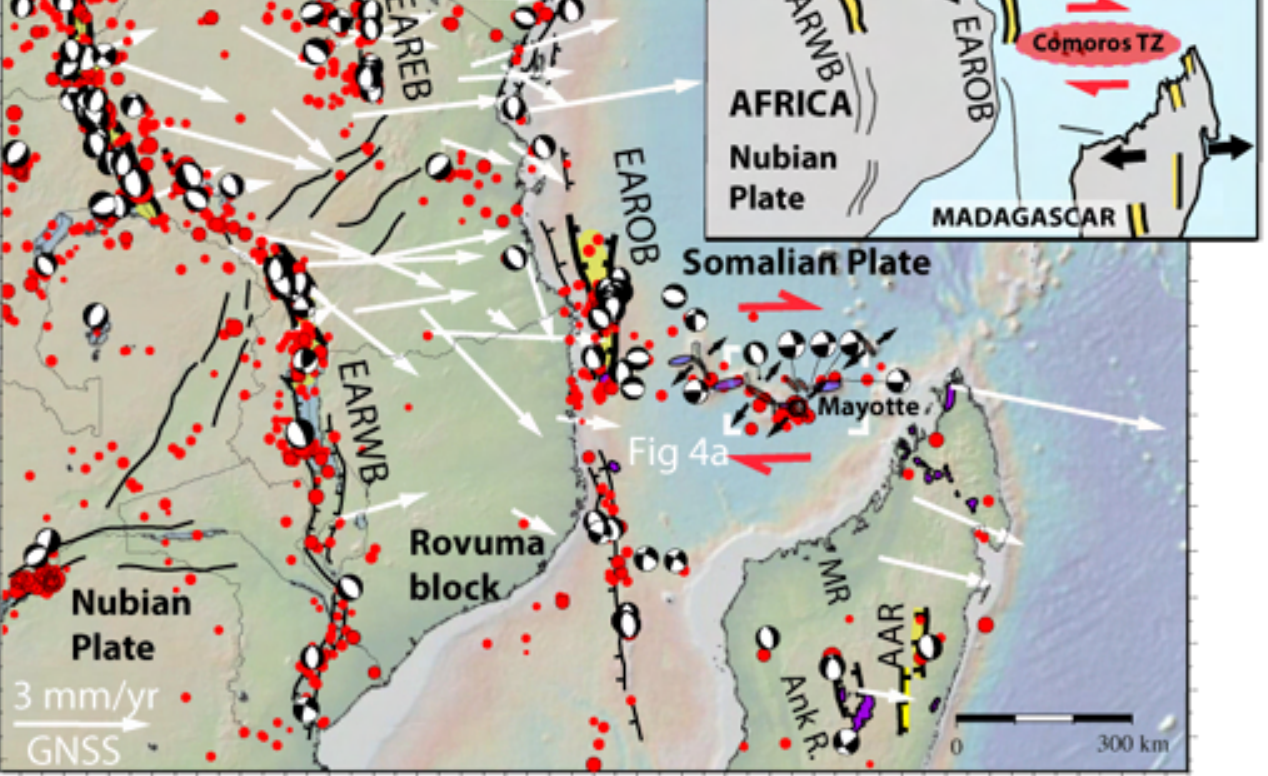

site

Nubiain

\section{Plate}
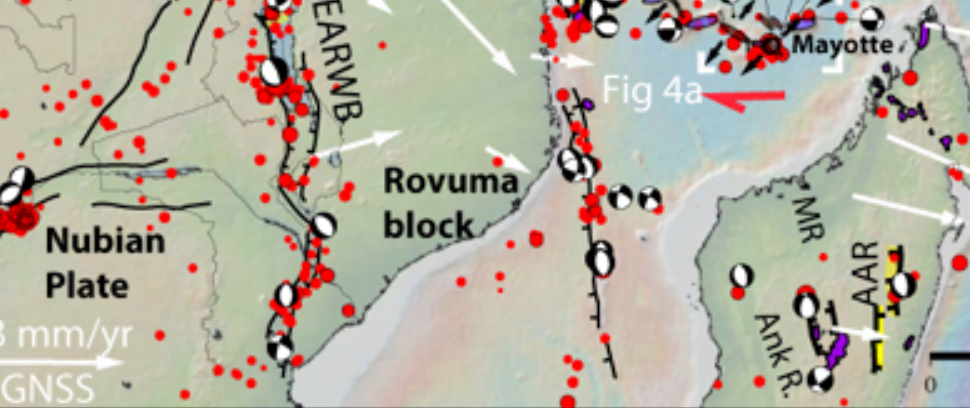

b)

Figure 5 